\title{
The Analysis of Income Statement and Final Balance Sheet in Local Governments: A Case Study for Financial Sustainability
}

\author{
Giovanna Lucianelli ${ }^{1}$, Amalia Lucia Fazzari ${ }^{1} \&$ Matteo Cavalieri ${ }^{1}$ \\ ${ }^{1}$ Department of Management and Law, University of Rome "Tor Vergata”, Rome, Italy \\ Correspondence: Giovanna Lucianelli, Department of Management and Law, University of Rome "Tor Vergata", \\ Rome, Italy. E-mail: lucianelli@economia.uniroma2.it
}

Received: December 3, 2019

Accepted: January 15, 2020

Online Published: February 20, 2020

doi:10.5539/ijbm.v15n3p80

URL: https://doi.org/10.5539/ijbm.v15n3p80

\begin{abstract}
The global financial crisis represents one of the main reasons for the situation suffered by many European countries both at national and local level.

Furthermore, the increased attention given to financial budgeting in the last years highlights the importance for public administrations to learn more about how to measure financial sustainability, how to implement strategies to avoid distress, and how to represent the expected results of these strategies.

We argue that a local government shows good financial conditions when it can provide public services without damaging its ability to face future obligations (GASB, 1987). On the contrary, local governments in poor financial health are unable to deal with their financial obligations and provide public services. Often, in this case, the quality or quantity of these services turns out to be damaged (Raphael, Renwick, Brown, \& Rootman, 2010).

It is essential to say that the level of financial condition cannot be easily represented since it cannot be readily measured by a single performance indicator, but rather it is determined by different measures directly observable.

We propose an explanatory case study to analyze the first results obtained through a plan devised to restore a good financial condition through a process of spending review in the municipality of Rome, one of the most important local governments. More specifically, we have analyzed the income statements and the final balance sheets for the years 2013-2017.

We further argue that our case study represents an inspiring strategy for financial sustainability thanks to an ad hoc legislation especially devised to overcome the crisis. Our case study also reveals all critical issues emerged during the analysis of the final data collected in the official documents drafted with accrual accounting across the five years.
\end{abstract}

Keywords: financial condition, accrual accounting, local governments, explanatory case study

\section{Introduction}

In the last decade several European countries, including Italy, have suffered from a financial vulnerability due to an unsustainable public debt accumulated over the years and to an uncontrolled increase of annual deficits. The financial crisis originated in countries such as Portugal, Ireland, and Greece and then extended to Spain and Italy in 2011. The turbulence in the financial markets and the contraction of loans granted by banks to companies contributed to slowing down the economic growth, and in some cases it caused an actual recession. Austerity policies implemented to contain expenditure were first adopted by the Governments of countries in economic distress and in a second time they were adopted by all the Member States of the European Union.

In Italy, the dynamics of indebtedness have become increasingly worrying within the public sector. In economic terms, the burdens of rescue operations of banks in crisis remained in charge of the State budget. Local authorities, although characterized by greater financial autonomy than in the past, had to adapt to stringent finance constraints. The Italian process of public accounts harmonization (implemented in 2015) and the greater empowerment of public decision-makers which followed the new structure of the spending programs emerged from the public accounting reform started in the year 2016 and the political discontinuities (coalition changes) in the municipalities have played a significant role in underlying the increasing imbalances in local accounts. Among other factors, the diminution of financial transfers from other levels of governments (from the Central 
Government in the first place) is responsible for the financial crisis in Italian Local Governments (ILGs), due to the gradual implementation of reforms which introduced a decentralized model and raising ILGs' economic autonomy.

The financial crisis of ILGs, between instability and rebalancing, has involved a total of more than 800 entities (just under $10 \%$ of the total) with a significant characterization concerning geographical distribution (IFEL, 2018).

The present work aims to analyze the income statements and the final balance sheets of the local government represented by the municipality of Rome (Roma Capitale), which is particularly interesting in terms of population density, geographical extension and amount of accumulated debt. Although Roma Capitale is not in a state of criticality (as it is not subjected to a rebalancing or collapsing procedure by Law), it has embarked on a process of rationalizing expenses which aims at gradually extinguishing the huge previous debts and at recovering economic efficiency.

The analysis was carried out both on the income statements and on the financial balance sheets (forecast budgets and final balance sheet accounts) published for the five-year period 2013-2017 which, as mentioned above, turned out to be full of changes both regulatory and political, and during a period in which various recovery plans were launched, both in terms of repayment of the debt and of cutting expenses.

At the local level, the harmonization of the accounting systems for ILGs was regulated by the legislative decree 118/2011 (fully operational after a period of testing in 2015) while new accounting standards were introduced by legislative decree n.126 of 10 August 2014, corrective and supplementary of 118/2011 (regulating planning, financial accounting, accrual accounting and the consolidated financial statements).

Analyzing such processes from a local government perspective allows to appraise the information of the shifting from the cash basis to the accrual accounting approach and thus represents a radical change in the literature on the subject. Up to now, the focus of investigation for financial crisis in Italian public organizations has been traditionally based on the official documents drafted with a cash-basis method.

\section{The Good Financial Condition of a Local Government: A Framework}

In general terms, financial conditions of a public-sector organization depend on internal factors that are represented by the availability of the resources required to maintain or improve the services provided to the citizens (Kloha, 2005; Audit Commission, 2007; Coe, 2008). Furthermore, external or environmental factors such as society's needs and preferences, socioeconomic characteristics of the population, the cost of the productive factors, the resources available to society, and the public policies affecting the local authority need to be taken into account. (Petersen, 1977; Berne \& Schramm, 1986; Berne, 1992; Boyne, 1996).

A public organization is considered in good financial condition when it meets its debts and in turn it provides acceptable levels of services. The financial health of a public sector organization could be articulated by observing a set of notorious indicators (Greenberg \& Hiller, 1995; CICA, 1997; Nollenberger, Groves \& Valente, 2003) about different aspects of solvency (budget solvency, short term/ long term solvency, service-level solvency). This concept is also necessary in order to verify the existence of the conditions for economic equilibrium for companies (Giannessi, 1960; Amaduzzi, 1978; Cavalieri, 2008), taking into account the political-institutional dimension that is combined with the standards of equity, legality and consensus representation (Borgonovi, 2004; Mussari, 2012).

A local government is considered in "good" financial condition when it can provide public services without damaging its ability to meet future obligations (GASB, 1987). It is worth underlining that if a local government is in poor financial health, the inability to meet its commitments determines the deterioration of the quality or the quantity of services offered to the community (Raphael, Renwick, Brown \& Rootman, 2010).

Financial problems are generally manifested as the inability to fulfill one's obligations and are usually accompanied by the related lack of available liquidity. The causes of "endogenous" nature can be traced back to various factors (Rasi, 2018): accounting disorder, accounting irregularities, scarce own revenue and / or inadequate collection capacity, stable recourse to cash advance, high expenses, rigid balance sheet, overestimation of the income, underestimation of costs, poor reliability of the residues. On the other hand, the causes of an "exogenous" nature, mainly depend on the continuous disturbances caused by the trend of the global economy.

In Italian business studies the topic of "financial sustainability" is analyzed through companies' ability to generate sufficient cash flows to guarantee loans repayment (Mulazzani, 2005) and "offer, in the case of private capital interventions, a mark-up as risk compensation". Notwithstanding this, the conditions of financial 
sustainability in a local government are not simple to represent, since they cannot be easily measured with a single measure expressing the optimal relationship between income and expenses, but rather they are determined by multiple factors and related indicators (Bisogno, Citro, \& Tommasetti, 2014; Manes Rossi, 2011; Anessi-Pessina, Sicilia \& Steccolini, 2012).

\section{Research Method}

This study has recourse to the theory to understand and explain the specificities of the rebalancing policies aiming to restore financial sustainability of the municipality of Rome.

Within our research framework, the ad-hoc legislation for saving the municipality of Rome from the crisis has been used to highlight similarities and differences between the case of the Italian Capital and other Italian cities in financial upset. In order to enrich the case study with financial information, we resorted and processed the financial data from official documents (The Special Commissioner's financial reports, Income Statements, and Final balance sheets). Furthermore, we studied the accrual accounts that were published even if not compulsory for the years 2013-2015 and the documents under the new legislation of the years 2016-2017. We also conducted informal interviews with the aim of clarifying some technical aspects not otherwise explained in official documents with public accounting experts such as the councilor responsible for accounts of the Municipality of Rome.

In this case study, we followed these steps:

a) Preparation. After reviewing the existing theories relevant to the case, a checklist of items to search for in the study has been developed (printing Italian Laws on ILGs and Law-Decrees for Rome and downloading other documents from official web sites);

b) Collecting and assessing the evidence. The preparatory review of theory has provided an initial indication of the types of evidence which should be looked after in the case study (collecting available financial reports of the municipality of Rome across years 2010-2017);

c) Identifying and explaining outlines. Various themes and patterns have emerged. Models (diagrams and tables) linking the multiple items and issues (e.g., the composition of passive mass of debt, the debt trend of Commissioner management for the years 2010-2016) have been prepared. The analysis has been developed taking into account the two areas of control in the Municipality of Rome after the Law Decree n. 112/2008: the extraordinary management of the Special Commissioner (for past debts emerged not later than April 28th, 2008) and the ordinary management (for the spending review control and the number of obligations developed for the years 2013-2017);

d) Report and conclusions. The analysis is presented in paragraph 4 to make the case and its explanations intelligible and plausible to readers, with the findings in section 5 , which also suggests possible directions for future research.

The overview of the Italian public financial management system depends both on TUEL as well as Legislative Decree 118/2011, introducing the so-called accounting harmonization reform.

\section{Case Study: The Municipality of Rome}

Roma Capitale is a territorial entity whose boundaries are those of the pre-existing municipality of Rome and is divided into 15 Municipalities; it has special statutory, administrative and financial autonomy. With its 2,8 million residents, Rome is the most populated municipality in Italy and the fourth in the European Union. It is located in the center of the Metropolitan City of Rome, which has 4,3 million residents.

The analysis of the deficit parameters attached to the Rome capital statements in the last 10 years shows that it is not a structurally loss-making entity even if it does not respect some of them.

The Italian Consolidated Text on the Law for Local Authorities (the so-called "TUEL" or Legislative Decree No. 267/2000) establishes the limits to indebtedness (ex-art. 204) and the indicators of imbalance (ex-art. 242, paragraph 2). The compliance of Rome with the parameters set by the Law has not proved sufficient to prevent the emergence of crisis situations (instability or pre-disruption). This aspect has been shown by some studies on the financial management of local authorities (De Toni 2017), based on elaboration of data contained in the reports of the Ministry of the Interior, of the Institute for Finance and Local Economy (IFEL, 2018) and of the Court of Accounts.

After a review process initiated by the "Observatory on Finance and Accounting of Local Authorities" on February 20th 2018, new indicators were launched for the three-year period 2019/2021. These indicators aimed at simplifying the obligations imposed on local authorities with reference to the monitoring activities of the 
economic-financial balances in order to control the revenue collection capacity, the indebtedness (with different levels of criticality: financial, emerged, in emergence, improper), the deficit and the rigidity of the expenditure. With respect to the issue of sustainability, two particularly significant threshold values appear among the eight parameters indicating an imbalance. The first one relates to the sustainability of financial debt, and the second one relates to the sustainability of the deficit. For the previous years, the inadequacy of legal parameters to represent the critical conditions made us deepen the economic meaning of the official accounts for ILGs.

We articulated the case study in two patterns: the extraordinary management for the debt repayment plans and the ordinary management for the spending review plan.

\subsection{Extraordinary Management: The Debt Repayment Plans}

The first plan to return from the previous indebtedness of the municipality of Rome was presented in 2008 and identified a deficit of just over 9,7 billion euro deriving from a difference between an active mass of 3 billion euros and a passive mass of more of 12,7 billion euros.

The extraordinary management assumed all the revenue and all the obligations accrued until April 28, 2008, even if the same were ascertained, and the related credits were settled with sentences published after the same date. At that time, the passive mass of debt (Figure 1) was composed of:

- 28 percent of non-financial liabilities (payments to various creditors) for a figure of 3,6 billion euros;

- 16.3 percent of payables to the public administration (P.A.), for about 2 billion euros;

- 55.7 percent from financial debts, for a stock of 7 billion and 128 million euros.

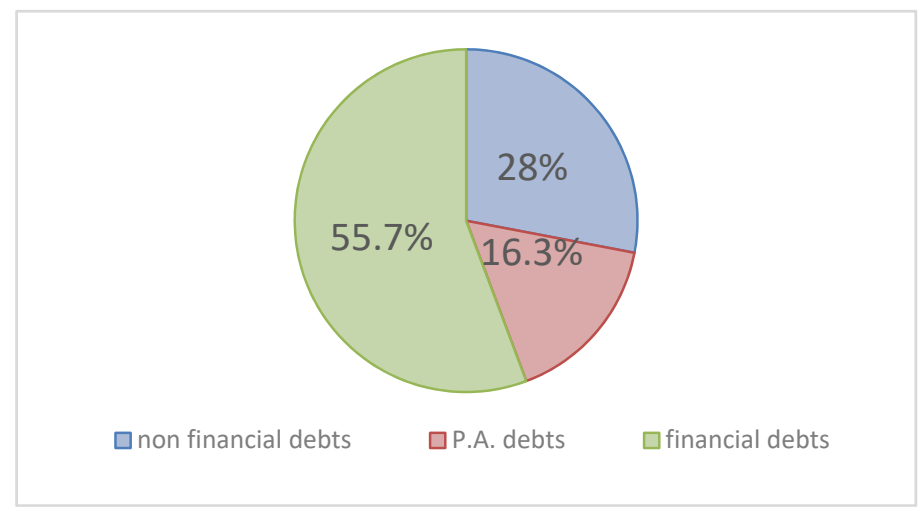

Figure 1. The composition of passive mass of debt

In 2010 a new repayment plan was prepared following the provisions of the decree-law n. 2 of 2010 which established that the Government Commissioner had to proceed to a definitive recognition of the active mass and passive mass, followed by the document of the final assessment of the debt in 2010. This document set a deficit of 16.7 billion, resulting from the difference between an active mass of 5 billion and 700 million, of which 81 million awaiting final settlement and a passive amount of 22.5 billion euro, of which 5.5 billion pending ultimate solution.

This increase in the deficit between the two plans, the one from 2008 and the other one from 2010, was represented by a different recording of interest expenditure which was not represented in the first plan, for a value of 6.7 billion euro, due to the effect of the emergence of new off-balance-sheet debts of 413 million euros and additional commitments of 286 million euros arising from litigation.

The fundamental problem is stated in the final assessment document of 2010. We find, for both the active mass and the passive mass, some components that are defined as "awaiting definitive verification". At the same time though neither the repayment plans were drawn up until now, nor the definitive debt verification document appears to contain an analytical analysis and an exhaustive representation of the financial situation to be restored prior to 2008.

It is worth observing that: 
- through $43 \%$ of the positions of the passive mass present in the computer system of the municipality of Rome (to which the extraordinary Commissioner refers) the creditor has not directly identified (12,000 positions for commercial debts); the passive mass from the financial point of view consists of 1,686 mortgages and 2 derivative contracts (out of the 9 inherited from the Municipality of Rome);

- through $29 \%$ of the credit positions (9,608 in total) of the active mass, the debtor is not directly identified (being in large part a list of assets and roles).

Structural financing was provided by law decree $\mathrm{n} .78$ of 2010: the annual State contribution found coverage for 300 million euros in a fund of the Ministry of the Economy and Finance and for 200 million euros in a fund fed with the additional tax on the rights of boarding of passengers on aircraft departing from the city of Rome and with an increase in the municipal income tax of $0,4 \%$.

In order to increase the liquidity of the extraordinary management through financial discounting operations, the Italian Government allocated 15 billion euros in its budget from the year 2011 to the year 2040. If we compare the present value of the financial debt up to 2048 with the State discounted contributions provided up to that date, we obtain that the financial debt is sustainable. More in detail, the financial debt is worth about 8,768,000 euros, whereas the current value of future contributions is around 8,974,000 euros: in this way, it slightly surpasses what is needed to repay the original debt.

In 2013, when the first extraordinary commissioner was about to conclude his mandate, a new mayor was elected and asked for additional funding to cover the debts arisen between 2008 and 2013; after that request the Government granted Roma Capitale a new extraordinary transfer of 110 million euros for the extra costs, due to its peculiar administrative status as Italy capital city.

In 2017, considering the other components of the repayment plan (trade payables, other new assets that emerged), the debt of the commissioner management has been considered financially sustainable considering "as the present value of the expected contributions added to the availability of cash is greater than the current value of payments of financial debts and foreseeable trade payables". However "the analysis of cash flows shows a risk of insolvency determined by liquidity crisis conditions in the management of payments" (Note 1) (the cash imbalance is expected from 2022 until 2032). The following figure 2 shows how the massive amount of debts has progressively decreased over the period 2010-2016.

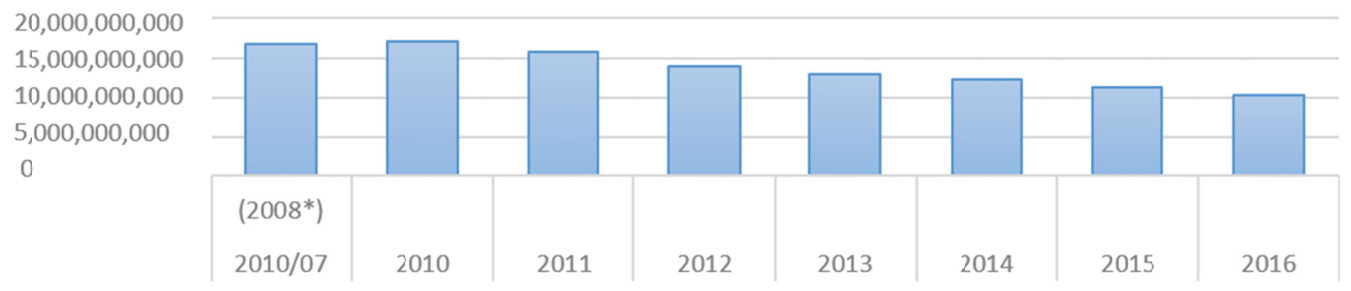

Figure 2. Debts trend commissioner management

Currently, to ensure the liquidity needed to meet the maturing obligations, the commissioner management is renegotiating the loans with the public entity for deposit and loan funds "Cassa Depositi e Prestiti" for a billion euros; and is procrastinating payment deadlines to 2048, although this might not be enough to clear the cash imbalance. It seems that there are no plausible alternatives: as a matter of fact, being served with future government contributions by banks is not convenient due to the high costs in terms of interests. The only way out consists in asking the Italian Government to nationalize part of the debt (through the tool of the "Colosseum Bond" that has its deadline in 2048).

\subsection{Ordinary Management: The Spending Review Plan}

In 2013 a structural disequilibrium of 550 million euros was ascertained every year, and accordingly, the debt repayment plan entailed a commitment to cut the "structural" expenses of $10 \%$ for three years (the years 2014-2016) for the municipality of Rome, for a partial amount of 440 million euros. A spending review was 
promoted through savings in the administrative structure and the investee companies (figure 3), while the remaining 110 million euros were charged to the Government for the recognition of extra costs incurred by Roman citizens for capital functions (which includes the additional personal income tax). The plan also provided for the identification of a stable loan from the Lazio Region of 240 million euros per year for Local Public Transport.

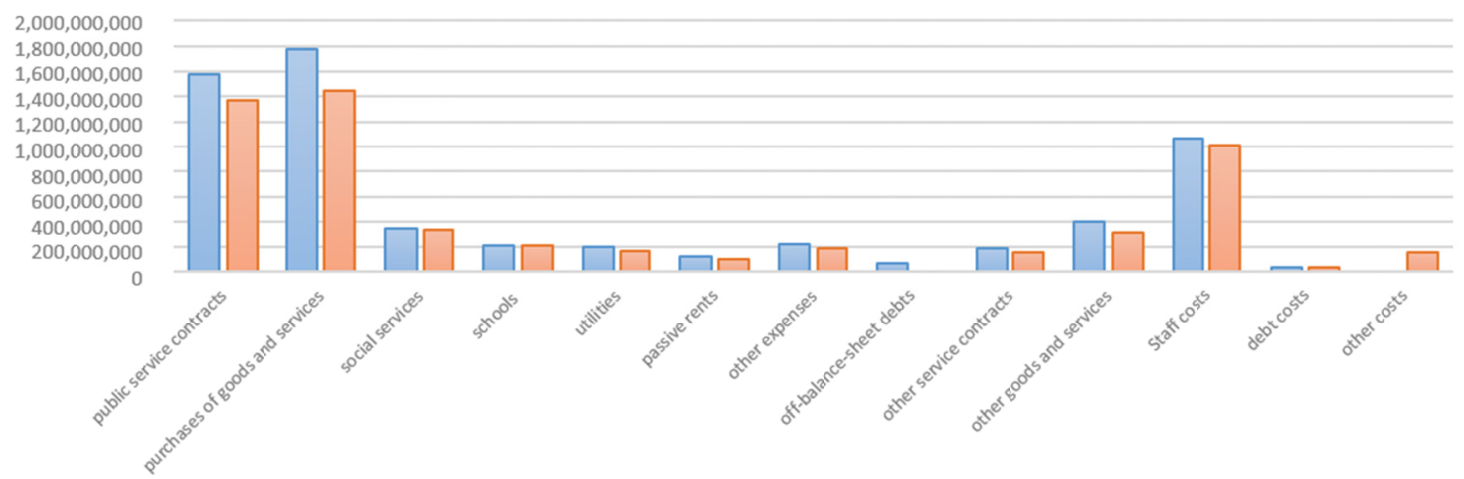

Figure 3. Historical structural expenditure (2009-2013) and spending review plan (2014-2016)

structural expenditure (2009-2013)

spending review (2014-2016)

Our analysis of the actual trend of the spending review for the first three-years (2014-2016), was carried out on the values indicated in the income statements (rather than on the financial data reported in the budgets). We were also adding the year 2013 (which precedes the period subject to the resizing of expenses) and the year 2017 (which follows the period in question) to have a more unobstructed view of the economic effects obtained thanks to the spending review policies.

The analysis we made on the expenses showed in accrual accounts published by the municipality of Rome revealed some criticalities: the values indicated for the years 2016/2017 were not fully comparable with those reported in the years $2013 / 2014 / 2015$. The criticalities are due to a series of Italian regulatory changes that have created a discontinuity in the items and the evaluation criteria, causing the incomparability of the official statements. We decided to separate the economic analysis in two periods (see table 1 and table 2): the first three years (2013-2015) and the second two years (2016-2017).

Table 1. Negative Management Components 2013 -2015 (euros)

\begin{tabular}{lrrr}
\hline & $\mathbf{2 0 1 3}$ & $\mathbf{2 0 1 4}$ & \multicolumn{1}{c}{$\mathbf{2 0 1 5}$} \\
\hline Staff costs & $1,023,838,544.47$ & $975,917,218.76$ & $911,160,028.56$ \\
Purchase of raw materials and consumer goods & $14,189,304.42$ & $12,628,980.90$ & $10,717,649.17$ \\
Services & $2,493,614,338.30$ & $2,687,292,931.05$ & $3,288,464,169.89$ \\
Enjoyment of third-party assets & $122,416,737.01$ & $113,592,408.92$ & $103,5888,262.80$ \\
Transfers and contributions & $757,385,305.97$ & $519,016,200.95$ & $375,116,462.76$ \\
Taxes & $65,580,816.99$ & $62,234,549.39$ & $59,357,476.53$ \\
Amortization and write-downs & $177,887,338.67$ & $185,170,296.83$ & $175,645,405.89$ \\
Change in inventories & $23,176.91$ & $38,666.01$ & $444,033.05$ \\
Financial charges & $31,701,154.74$ & $32,602,012.37$ & $32,169,440.32$ \\
Extraordinary charges & $518,047,568,38$ & $590,913,947,05$ & $507,732,121,98$ \\
Transfers to special companies & $23,932,740.53$ & $22,160,360.05$ & $35,910,798.60$ \\
Income taxes & $65,580,816.99$ & $62,234,549.39$ & $59,357,476.53$ \\
Total & $\mathbf{5 , 2 9 4 , 1 9 7 , 8 4 3 . 3 8}$ & $\mathbf{5 , 2 6 3 , 8 0 2 , 1 2 1 . 6 7}$ & $\mathbf{5 , 5 5 8 , 7 7 5 , 2 5 9 . 9 8}$ \\
\hline
\end{tabular}

Source: Municipality of Rome (2013-2015). 
As shown in table 2, the main items under the plan of spending review decreased progressively over the first three years (staff costs, the purchase of raw materials and consumer goods, the use of third-party assets, the transfers relating to all grants to third parties). In reading the data of assignments, it is worth considering the amount of $200,000,000$ euros compared to the transfer to the Government for the financing of the commission re-entry plan, which is also present in all three years. Also, the item taxes and duties show a decrease, which is mainly due to the reduction of the regional tax on productive activities. The amortization does not show significant changes over the three years; the most significant component is represented by the depreciation of buildings, which are part of the unavailable assets to which the devaluation of government assets follows in order of numerical impact.

At the operational level, only the cost of services has increased in the three years.

The financial charges show a non-linear trend in the three years under review. Since the costs are substantially higher than the income, the financial management result is always negative in the period considered and shows a worsening of the balance conditions.

The extraordinary costs in the three years are fluctuating with a decrease of approximately 10,000,000 euros, which is marginal to the total initial amount.

In conclusion, we noted a general increase in the amount of the negative management components for the years $2013 / 2015$, even though we expected a decrease in their amount.

Table 2. Negative components of 2016-2017 management (euros)

\begin{tabular}{lrr}
\hline & \multicolumn{1}{c}{} & $\mathbf{2 0 1 6}$ \\
\hline Purchase of raw materials and consumer goods & $8,835,984.38$ & $10,923,315.15$ \\
Provision of services & $2,671,001,027.68$ & $2,573,809,908.50$ \\
Enjoyment of third-party assets & $96,769,461.34$ & $88,345,305.86$ \\
Transfers and contributions & $371,098,062.49$ & $405,787,492.62$ \\
Current transfers & $351,773,175.10$ & $381,886,173.96$ \\
Investment grants to Public Administrations & $1,675,309.65$ & - \\
Investment grants to other parties & $17,649,577.74$ & $23,901,318.66$ \\
Staff costs & $895,341,879.53$ & $981,375,052.56$ \\
Amortization, depreciation and write-downs & $169,392,937.10$ & $972,435,839.25$ \\
Amortization of intangible assets & $4,005,887.25$ & $19,828,171.09$ \\
Depreciation of tangible fixed assets & $165,387,049.85$ & $103,201,703.76$ \\
Other write-downs of fixed assets & - & - \\
Write-down of receivables & - & $849,405,964.40$ \\
Changes in inventories of raw materials and/or consumer goods & $91,018.39$ \\
Provisions for risks & $-393,443.23$ & $267,284,800.47$ \\
Other Provisions & $66,620,026.77$ & - \\
Other operating expenses & $311,425,479.78$ & $60,699,182.70$ \\
Financial charges & $78,539,420.54$ & 45.647 .139 .02 \\
Extraordinary charges & $30,063,818.21$ & 357.627 .690 .44 \\
Transfers to special companies & $110,415,864.82$ & 0 \\
Income taxes & & $49,661,983.69$ \\
Total negative components & $45,522,499.85$ & $\mathbf{5 , 8 1 3 , 6 8 8 , 7 2 8 . 6 5}$ \\
\hline
\end{tabular}

Source: Municipality of Rome (2016-2017).

In this second period of analysis we observed a significant increase in some items of expenditures: purchase of raw materials and consumer goods, staff costs, transfers and contributions to other public or private administrations (the most significant item of the transfers is that relating to the transfer to the State for 200,000,000 for financing the commission re-entry plan), provisions for risks, changes in inventories of raw materials, financial charges ( this is due to the early repayment of some loans).

More in detail, amortization, depreciation, and write-downs increased in 2017; as we mentioned above, the main reason for such situation should be ascribed to the inclusion in this item of the write-down of receivables for about $849,000,000$ euros, previously present in the item "other provisions", which is therefore zeroed. Some other costs decreased: cost of services, the use of third-party assets (attributable to the decrease in the item lease of real estate) other provisions, other operating expenses. 
The most significant change can be found in the item "extraordinary charges" mostly related to the increase in contingent liabilities and the non-existent assets. Contingent liabilities refer to the payment made by the treasurer against the ordinary cash of the loan installments present in the commissioner management and not regularized in financial accounting as well as to the correction of values current at the time of opening the balance sheet; the non-existence of assets refers to the cancellation of receivables.

In conclusion, we observed a general increase in the negative components also for the years 2016/2017 instead of the expected decrease.

It is worth observing that our analysis confirms an initial decrease in operating costs for the main items, except for expenses for services that increase up to 2015 and then begin to decrease in the last two years. Financial charges remained substantially stable until 2016, while in the previous year, they increased by 1.5 million euros or $50 \%$ compared to past years, but the difference relates to the early repayment of some loans and not to a deterioration in the financial situation.

On an aggregate level, it is useful to observe the contribution that the various management activities have made to the final economic result of each of the years considered (see table 3 ).

Table 3. Aggregate results of operations for the years 2013-2017 (euros)

\begin{tabular}{|c|c|c|c|c|c|c|}
\hline $\begin{array}{l}\text { Classification of items } \\
\text { years } 2013-2015\end{array}$ & 2013 & 2014 & 2015 & 2016 & 2017 & $\begin{array}{l}\text { Classification of items years } \\
2016-2017\end{array}$ \\
\hline $\begin{array}{l}\text { Results of operational } \\
\text { management }\end{array}$ & $348,767,222,45$ & $439,648,352,03$ & $134,395,769,91$ & $225,435,777,91$ & $-409,220,351,70$ & $\begin{array}{l}\text { Difference between positive } \\
\text { and negative management } \\
\text { components (A-B) }\end{array}$ \\
\hline $\begin{array}{l}\text { Results of financial } \\
\text { management }\end{array}$ & - $15,402,712,00$ & - $11,476,903,69$ & $\begin{array}{r}- \\
19,254,357,75\end{array}$ & $51,476,885,65$ & $42,531,211,28$ & $\begin{array}{l}\text { Total financial income and } \\
\text { charges }(\mathrm{C})\end{array}$ \\
\hline $\begin{array}{l}\text { Results of } \\
\text { extraordinary } \\
\text { management }\end{array}$ & $-363,830,109,01$ & $-364,046,900,53$ & $403,107,658,97$ & $45,710,723,36$ & $507,331,217,47$ & $\begin{array}{l}\text { Total extraordinary income } \\
\text { and charges }(E)\end{array}$ \\
\hline $\begin{array}{l}\text { Economic Result of } \\
\text { the year }\end{array}$ & - $30,465,598,56$ & $64,124,547,81$ & $518,249,071,13$ & $277,100,887,07$ & $110,213,320,40$ & Economic Result of the year \\
\hline
\end{tabular}

Source: Municipality of Rome (2017).

The correlation of the results of the different management activities in the five years is represented below (figure 4).

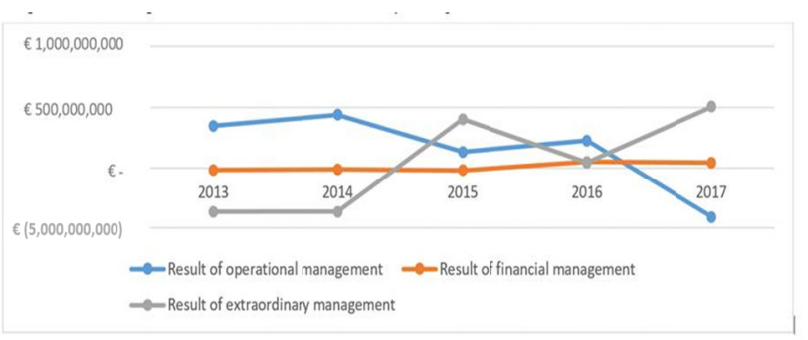

Figure 4. Results of operational/financial and extraordinary management (2013-2017)

The economic result over the three years substantially improves, moving from a negative amount of $30,465,598$ for 2013 to a positive outcome of 518,249,071 for 2015. The leading cause can be found in the elements of extraordinary management and in particular, in the cancellation of some liabilities; for the subsequent two-year period 2016 and 2017, the result for the year once again decreased. The cause, however, seems to be ascribable to a reduction in the contribution of extraordinary management in the year 2016: in particular, the item of extraordinary income decreased for the year 2016 of about 700 million euros compared to the previous year.

We should also consider that in 2017 , the item write-down of receivables was increased by $849,405,964.40$ euros, and this mainly contributes to depressing the economic result; in the previous year write-down of receivables was 
included in the item other provisions for $311,425,479.78$ and shows an increase in the last financial year of approximately 537 million euros.

The economic results for 2016 and 2017 cannot be considered worsened if compared to those achieved in 2015. All those items recording a reduction in their amount have an extraordinary nature and are determined by the accounting changes not attributable to the financial year in which they appear in the financial statements.

We can have a better perception of the trend over the years, find it in figure 5 .

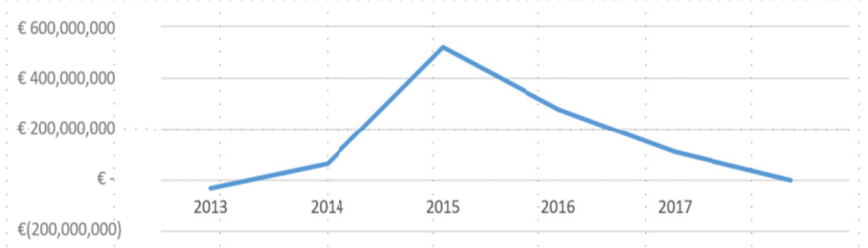

Figure 5. Economic result of the years 2013-2017

\subsection{Ordinary Management: The Analysis of the Liabilities in Final Balance Sheet Items}

The third path in our study has focused on the observation of the components of the final balance sheet to evaluate the effectiveness of the debt repayment plans. We proceeded by observing the performance of the individual items and their aggregates about the 2013-2017 period. We have taken into account the trend of the values and the information in the official Reports that accompanied the prospectuses of each final balance sheet.

As a preliminary matter, it should be noted that the representation of the balance sheet values shows a discontinuous trend regarding the 2016-2017 two-year period compared to the previous three years 2013-2015. This discontinuity is underlined in the statements of the Balance Sheet also for the valuation criteria adopted.

Within the limits of these premises, we proceeded to analyze the values for the entire observation period to give an overall view of the Liabilities.

The analysis of the passive items of the Balance Sheets shows a strong differentiation in the composition of the sources (figure 6) in the three years 2013-2015 compared to the 2016-2017 two-year period; this differentiation is affected by the different exposure and classification of values which makes them incomparable to each other as reported above.

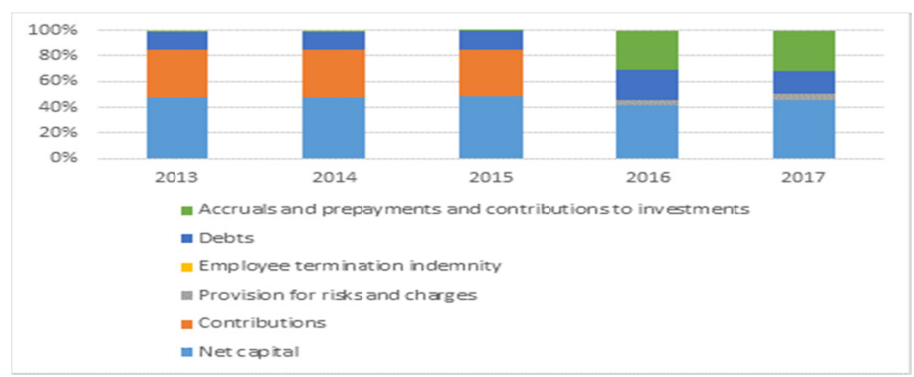

Figure 6. Sources composition

In fact, with regard to the item Debts, it presents a differentiation in the classification and presentation of values in the two periods analyzed; while in the 2013-2015 period there was a subdivision of the amounts into Loans and Other Payables, in 2016-2017 - it includes a synthetic exposure in a single item as shown in the table and graph below (see table 4). 
Table 4. Composition of debts

\begin{tabular}{|c|c|c|c|c|c|}
\hline & 2013 & 2014 & 2015 & 2016 & 2017 \\
\hline Debts & & & & $5,065,981,998,10$ & $3,563,369,095,71$ \\
\hline Financial debts & $1,220,331,095,45$ & $1,214,739,040,41$ & $1,208,689,548,64$ & & \\
\hline Other debts & $1,670,698,905,38$ & $1,771,373,598,18$ & $1,847,611,034,15$ & & \\
\hline
\end{tabular}

Despite the different exposure of the values in the 2013-2017 period, the trend in debts shows an increase of $66 \%$ in 2016 compared to the previous year and a subsequent reduction of $30 \%$ in 2017 . More in detail, the composition of the item Debts in 2017 concerns (figure 7) financial debts and other debts, but the analytical amount of them is not described in the accompanying Report for the year 2016-2017. (Note 2)

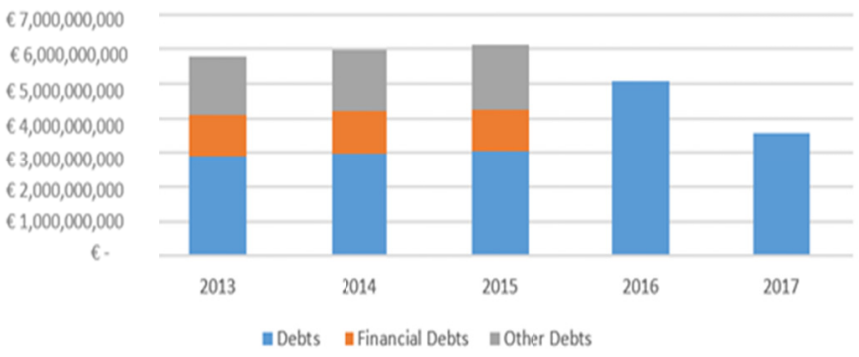

Figure 7. Debts trend Ordinary management 2013-2017

\section{Conclusions and Directions for Future Research}

The starting point of this paper was an analysis of the current literature on how to define a good financial condition in ILGs. The paper intended to study the case of Rome to identify the effectiveness of the strategies undertaken for restoring financial health after the considerable amount of debts accumulated over the years. We have preferred the tool of income statements and balance sheets analysis over other indicators to deepen the financial and economic situation. In a previous study (Lucianelli, Citro, Santis, Tranfaglia \& Mazzillo, 2018) we focused on the specific measures for budgetary solvency: sustainability, flexibility, and vulnerability as measurement to restore financial health; in this paper we meant to determine whether the announced plans of spending review could be considered successful after the period of managing costs and if the vast debt has been actually reduced.

As specified above, the analysis of the income statements has revealed a reduction in costs, only for some items. For other items, the effect was the opposite. The observation over the five years proved quite difficult in reaching the goal of the "cost-efficiency plan" also for the significant amount of write-down of receivables, which have become compulsory according to the new accounting rules.

The analysis on the balance sheets revealed a reduction of the total amount of debt both in extraordinary management and in ordinary management. However, we should keep in mind that the total amount of debt in 2017 has also been reduced for legislative changes (introduced for making the budget and the final balance sheet more truthful). Through the new process of harmonization of the Italian accounting systems (envisaged by Law $\mathrm{n}$. 196/2009 with the various implementing decrees including Legislative Decree n. 118/2011 and subsequent ones), a new concept of competence has been introduced, that "enhanced" the statement of financial reporting. This concept underlines that all the legally perfected active and passive obligations, which give rise to income and expenses for the institution, must be recorded in accrual accounting when the debts are considered "legally perfected"; it means that the maturity of the obligation happens in the time when the bond becomes payable.

The correct application of the new accounting standards allows us to know the actual debts of the P.A., to avoid the assessment of future revenues and non-existent commitments, to strengthen the budget planning, to favor the modulation of obligations according to the actual needs and, finally, to bring the financiall competence of income and expenses closer to the economic components of revenues and costs.

The debt repayment plans appear effective; nonetheless the reduction in 2017 of the total amount of debt could be partly due to the change in the standard of the "enhanced financial competence" introduced in 2016. 
Considering the significant amount of the positive economic result of 2015, we need to highlight that this has been undoubtedly influenced by the transition to the new harmonized accounting system, which led to a considerable reduction in the residual liabilities. In summary, we cannot affirm that the spending review project was useful if we do not have information concerning the quality of services of the municipality; it seems that the spending review process only concerned those components subject to observation by the Government and allowed the use of other items to increase. The spending review program can be considered ineffective only if we are sure that the quality of public service has not improved during the period observed. This aspect could be further analyzed in a future step of this research.

It is probably too early to evaluate the overall effects of the strategies of financial sustainability for the shifting from cash basis to accrual accounting approach in ILGs accounting system.

The present research suggests that the use of income statements and balance sheets for the analysis of financial sustainability in public administration is a powerful tool, and that is precisely why it must be implemented very carefully.

Finally, we argue that this study can contribute to the debate on both the theoretical and practical underpinnings to represent the financial sustainability in local governments and analyze the effectiveness of the plans for the repayment of the debt and the spending review program through the renewed financial accounting approach.

\section{References}

Amaduzzi, A. (1978). L'azienda nel suo sistema e nell'ordine delle sue rilevazioni, Utet, Torino, 74-75

Anessi-Pessina E., Sicilia M. F., \& Steccolini I. (2012). Budgeting and Rebudgeting in Local Governments: $\begin{array}{llll}\text { Siamese Twins? Public Administration Review, 72(6), 875-884. } & \text {. }\end{array}$ http://dx.doi.org/10.1111/j.1540-6210.2012.02590.x

Audit Commission. (2007). Use of Resources. Guidance for Councils, Audit Commission, London. Retrieved from https://www.croydon.gov.uk/sites/default/files/articles/downloads/resources.pdf

Bailey, S. J., Valkama, P., \& Salonen, S. (2014). The EU's public finance crisis: causes, consequences and cure. Public Money \& Management, 34(2), 83-90. http://dx.doi.org/10.1080/09540962.2014.887514

Barbera, C., Jones, M., Korac, S., Saliterer, I., \& Steccolini, I. (2017). Governmental financial resilience under austerity in Austria, England and Italy: How do local governments cope with financial shocks? Public Administration, 95(3), 670-697. https://doi.org/10.1111/padm.12350

Berne, R. (1992). The Relationships between Financial Reporting and the Measurement of Financial Condition. Research Report No. 18, GASB. Norwalk, CT

Berne, R., \& Schramm, R. (Eds.) (1986). The Financial Analysis of Governments. NJ: Prentice Hall

Bisogno M., Cuadrado-Ballesteros, B, \& García-Sánchez, I. M. (2017). Financial sustainability in local governments: definition, measurement and determinants, In Rodríguez Bolívar, Manuel Pedro (Eds.), Financial sustainability in public administrations. Exploring the Concept of Financial Health (pp. 57-83). Palgrave Macmillan. http://dx.doi.org/10.1007/978-3-319-57962-7

Bisogno, M., \& Cuadrado-Ballesteros, B. (2017). Explaining the relation between efficiency and financial condition: Empirical analysis on Italian local governments, In Rodríguez Bolívar, Manuel Pedro \& López Subires, María Deseada (Ed.), Financial Sustainability and Intergenerational Equity in Local Governments. IGI Global. http://dx.doi.org /10.4018/978-1-5225-3713-7

Bisogno, M., Citro, F., \& Tommasetti, A. (2014). The Financial Distress of Public Sector Entities: Evidence from Italian Public Universities. International Journal of Accounting, Auditing and Performance Evaluation, 10(2), 203-227. https://doi.org/10.1504/IJAAPE.2014.060221

Borgonovi, E. (2004). Principi e sistemi aziendali per le amministrazioni pubbliche. Egea, Milano.

Boyne, G. A. (1996). Constraints, Choice and Public Policies (1st ed.). London: JAI Press.

Cabaleiro, R., Buch, E., \& Vaamonde, A. (2013). Developing a method to assessing the municipal financial health. The American Review of Public Administration, 43(6), 729-751. https://doi.org/10.1177\%2F0275074012451523

Capalbo, E., \& Grossi, G. (2014), Assessing the influence of socioeconomic drivers on Italian municipal financial destabilization, Public Money \& Management, 34(2), 107-114. https://doi.org/10.1080/09540962.2014.887518 
Carmeli, A. (2003), Introduction: fiscal and financial crises of local governments, International Journal of Public Administration, 26(13), 1423-1430. https://doi.org/10.1081/PAD-120024404

Carmeli, A. (2008). The Fiscal Distress of Local Governments in Israel: Sources and Coping Strategies. Administration and Society, 39, 984-1007. https://doi.org/10.1177\%2F0095399707309358

Cavalieri, E. (2008). Economia Aziendale. Attività aziendale e processi Produttivi, 1, 221-224

Checherita-Westphal, C., Hughes Hallett, A., \& Rother, P. (2014). Fiscal sustainability using growth-maximizing debt targets. Applied Economics, 46(6), 638-647. http://dx.doi.org/10.1080/00036846.2013.861590

CICA. (1997). Indicators of Government Financial Condition. Canadian Institute of Chartered Accountants: Toronto

CICA. (2009). Public Sector Statements of Recommended Practice (SORP) 4. Indicators of Financial Condition. Canadian Institute of Chartered Accountants: Toronto.

CIPFA, (2014). Risk, Resilience and Reform, CIPFA Annual Conference 2nd to 3rd July 2014, London.

Coe C. K. (2008). Preventing local government fiscal crises: emerging best practices. Public Administration Review, 68(4), 759-767. http://dx.doi.org/10.1111/j.1540-6210.2008.00913.x

Cohen, S., Doumpos, M., Neofytou, E., \& Zopounidis, C. (2012). Assessing financial distress where bankruptcy is not an option: An alternative approach for local municipalities. European Journal of Operational Research, 218(1), 270-279. https://doi.org/10.1016/j.ejor.2011.10.021

Cuadrado-Ballesteros, B, Mardàn, N., \& Frías-Aceituno (2016). Transparency as a Determinant of Local Financial Condition, In Augusta da Conceição Santos Ferreira; Graça Maria do Carmo Azevedo; Jonas da Silva Oliveira \& Rui Pedro Figueiredo Marques (Eds.), Global Perspectives on Risk Management and Accounting in the Public Sector (pp. 202-225). IGI Global.

Cuadrado-Ballesteros, B., Mordán, N., \& García-Sánchez, I. M. (2014). Is Local Financial Health associated with Citizens' Quality of Life? Social Indicators Research, 119, 559-580. https://doi.org/10.1007/s11205-013-0533-2

De Toni, A. (2017). Lo stato di crisi negli enti locali, Fondazione nazionale commercialisti, https://www.fondazionenazionalecommercialisti.it/node/1243

Dollery, B., Crase, L., \& Byrnes, J. (2006). Local government failure: why does Australian local government experience permanent financial austerity? Australian Journal of Political Science, 41(3), 339-353. http://dx.doi.org/10.1080/10361140600848952

Dollery, B., \& Grant, B. (2011). Financial Sustainability and Financial Viability in Australian Local Governments. Public Finance and Management, 11(1), 28-47.

European Union. (2012). Fiscal Sustainability Report. European Commission: Brussels.

European Union. (2015). Fiscal Sustainability Report. European Commission: Brussels.

GASB. (1987). Concepts Statement $N^{o} 1$ of Governmental Accounting Standards Board: Objectives of Financial Reporting. Governmental Accounting Standards Board: Norwalk.

García-Sánchez, I. M., Mordán, N., \& Prado-Lorenzo, J. M. (2012). Effect of the Political System on Local Financial Condition: Empirical Evidence for Spain's largest Municipalities. Public Budgeting and Finance, 32(2), 40-68. https://doi.org/10.1111/j.1540-5850.2011.00986.x

García-Sánchez, I. M., Mordán, N., \& Cuadrado-Ballesteros, B. (2014). Do Electoral Cycles affect Local Financial Health? Policy Studies, 35(6), 533-556. https://doi.org/10.1080/01442872.2014.971727

Giannessi, E. (1960). Le aziende di produzione originaria, 1, 72-73. Colombo Cursi, Pisa.

Greenberg J., \& Hiller, D. (1995) Indicators of financial condition for governments. Paper presented at the 5th Conference of Comparative International Governmental Accounting Research, Paris-Amy. Retrieved from http://www.iceis.org/iceis2005/abstracts_2005.htm

Groves, M., Godsey, W., \& Shulman, M. (1981). Financial indicators for local government. Public Budgeting \& Finance, 1(2), 5-19. http://dx.doi.org/10.1111/1540-5850.00511

Guarini, E. (2016). The day after: newly-elected politicians and the use of accounting information. Public Money \& Management, 36(7), 499-506. https://doi.org/10.1080/09540962.2016.1237135

Hendrick, R. (2004). Assessing and measuring the fiscal heath of local governments: Focus on Chicago suburban 
municipalities. Urban Affairs Review, 40(1), 78-114. https://doi.org/10.1177/1078087404268076

Honadle, B.W. (2003). The states' role in U.S. local government fiscal crises: a theoretical model and results of a national survey. International Journal of Public Administration, 26(13), 1431-1472. http://dx.doi.org/10.1081/PAD-120024405

IFEL (2018). $\quad$ Il bilancio $2018 . \quad$ Retrieved from http://www.fondazioneifel.it/documenti-e-pubblicazioni/item/9491-il-bilancio-2018

IMF (International Monetary Fund) (2014). Vertical Fiscal Imbalances and the Accumulation of Government Debt. No.14/209. Washington, DC: IMF. https://doi.org/10.2139/ssrn.2464920

Inman, R. P. (1995). How to have a fiscal crisis: Lessons from Philadelphia. American Economic Review, 85(2), $378-383$

IPSASB. (2013). Reporting on the Long-term Sustainability of an Entity's Finances. International Public Sector Accounting Standards Board: New York.

Jones, S., \& Walker, R. G. (2007). Explanators of Local Government Distress. Abacus, 43(3), 396-418. http://dx.doi.org/10.1111/j.1467-6281.2007.00238.x

Kloha, P., Weissert, C. S., \& Kleine, R. (2005). Developing and testing a composite model to predict local fiscal distress. Public Administration Review, 65(3), 313-323. http://dx.doi.org/10.1111/j.1540-6210.2005.00456.x

Lohri, C. R., Camenzind, E. J., \& Zurbrügg, C. (2014). Financial Sustainability in Municipal Solid Waste Management: Costs and Revenues in Bahir Dar, Ethiopia. Waste Management, 34, 542-552. https://doi.org/10.1016/j.wasman.2013.10.014

Lopez-Hernández, A. M., Zafra-Gómez, J. L., \& Ortíz-Rodríguez, D. (2012). Effects of the Crisis in Spanish Municipalities' Financial Condition: An Empirical Evidence (2005-2008). International Journal of Critical Accounting, 4(5/6), 631-645. https://doi.org/10.1504/IJCA.2012.051457

Lucianelli, G., Citro, F., Santis, S., Tranfaglia, A.E., \& Mazzillo, A. (2018). How to improve the financial conditions of local governments in a period of crisis: an explanatory case study, International Journal of Business and Management, vol. 13, n.1. https://doi.org/10.5539/ijbm.v13n1p53

Manes Rossi, F. (2011). Analysis of Solvency in Italian Local Governments: The Impact of Basel III, the ICFAI journal of financial risk management. http://dx.doi.org/10.2139/ssrn.1830520

Mulazzani, M. (2005). L'evoluzione del sistema contabile nel quadro dell'aziendalizzazione degli enti locali, Azienditalia, n.1.

Mussari, R., (2012), Brevi considerazioni sui mutamenti in atto nei sistemi di contabilità pubblica. Azienda Pubblica, 1, 11-21.

Mussari, R., \& Giordano, F. (2013). Emerging Issues in Italian Fiscal Federalism: The Case of Municipalities. In Denita Cepiku-David K. Jesuit-Ian Roberge (Eds.), Making Multilevel Public Management Work: Stories of Success and Failure from Europe and North America (pp. 27-50). https://doi.org/10.1201/b14752

Mussari, R., Tranfaglia, A. E., Reichard, C., Bjorna, H., Nakrosis, V., \& Bankauskaite, S. (2016). Design, Trajectories of Reform, and Implementation of Performance Budgeting in Local Governments: A Comparative Study of Germany, Italy, Lithuania, and Norway. In Sabine Kuhlmann and Geert Bouckaert (Eds.), Local Public Sector Reforms in Times of Crisis (pp. 101-119). https://doi.org/10.1057/978-1-137-52548-2_6

National Audit Office. (2013). Financial Sustainability of Local Authorities 2013 [The Comptroller and Auditor General], HC 888 Session 2013/14 30 January 2013, London: The Stationery Office.

Nollenberger, K., Groves, S. M., \& Valente, M. G. (Eds.). (2003). Evaluating Financial Condition: A Handbook for Local Government. Washington, DC: IC/CMA.

Pagano, M., \& Moore, R. J. T. (Eds.) (1985). Cities and fiscal choices: a new model of urban public investment. Duke University Press.

Parker, L. (2014). Qualitative perspectives: Through a methodological lens. Qualitative Research in Accounting \& Management, 11(1), 13-28. https://doi.org/10.1108/QRAM-02-2014-0013

Paulais, T. (2009). Local Governments and the Financial Crisis: An Analysis (1st eds.). Washington, DC, The Cities Alliance. 
PARK, K. (2004), To file or not to file: the causes of municipal bankruptcy in the united states. Journal of public budgeting, accounting \& financial management, 16(2), 228-256.

Pérez-López, G., Plata-Díaz, A. M., Zafra-Gómez, J. L., \& López-Hernández, A. M. (2013). Deuda viva municipal en un contexto de crisis económica: análisis de los factores determinantes y de las formas de gestión. Revista de Contabilidad-Spanish Accounting Review, 16(2), 83-93. https://doi.org/10.1016/j.rcsar.2012.12.001

Petersen, J. E. (1977). Simplification and standardization of State and Local Government fiscal indicators. National Tax Journal, 30(3), 299-311.

Raphael, D., Renwick, R., Brown, I., \& Rootman, I. (2010). Quality of life indicators and health. In D. Raphael (Ed.), Health promotion and quality of life in Canada. Toronto: Canadian Scholars' Press.

Rasi, I. (2018). Le cause di squilibrio e i nuovi parametric deficitari, IFEL -Fondazione ANCI.

Scapens, R. W. (1990). Researching Management Accounting Practice: The role of case study methods. British Accounting Review, 22, 259-281. https://doi.org/10.1016/0890-8389(90)90008-6

Steccolini, I., Barbera, C., \& Jones, M. (2015). Governmental financial resilience under austerity: The case of English local authorities. CIMA Executive Summary Report, 11(3), 1-13.

Zafra-Gómez, J. L., López-Hernández, A. M., \& Hernández-Bastida, A. (2006). Evaluación de la condición financiera de las administraciones locales a través del análisis de componentes principales. Presupuesto y Gasto Público, 43, 113-126.

Zafra-Gómez, J. L., López-Hernández, A. M., \& Hernández-Bastida, A. (2009). Evaluating Financial Performance in Local Government: Maximizing the Benchmarking Value. International Review of Administrative Science, 75(1), 151-167. https://doi.org/10.1177\%2F0020852308099510

\section{Notes}

Note 1. Report on the activities carried out by the commissioner management for the repayment plan of the previous debt of Rome capital - year 2017, 6 September 2018, p. 21.

Note 2. 004_Annex B3 Economic Analysis of Liabilities 2017_1 page 38.

\section{Copyrights}

Copyright for this article is retained by the author(s), with first publication rights granted to the journal.

This is an open-access article distributed under the terms and conditions of the Creative Commons Attribution license (http://creativecommons.org/licenses/by/4.0/). 